\title{
Diphosphine-bridged digold(I) compounds: Structural and computational studies on the aurophilic interaction in $\mathrm{Au}_{2} \mathrm{Cl}_{2}\left(\mu\right.$-bpcd) and $\mathrm{Au}_{2} \mathrm{Cl}_{2}(\mu$-bmi)
}

Rogers Nyamwihura, Li Yang, Vladimir N. Nesterov, and Michael G. Richmond*

Department of Chemistry, University of North Texas, Denton, TX 76203, USA

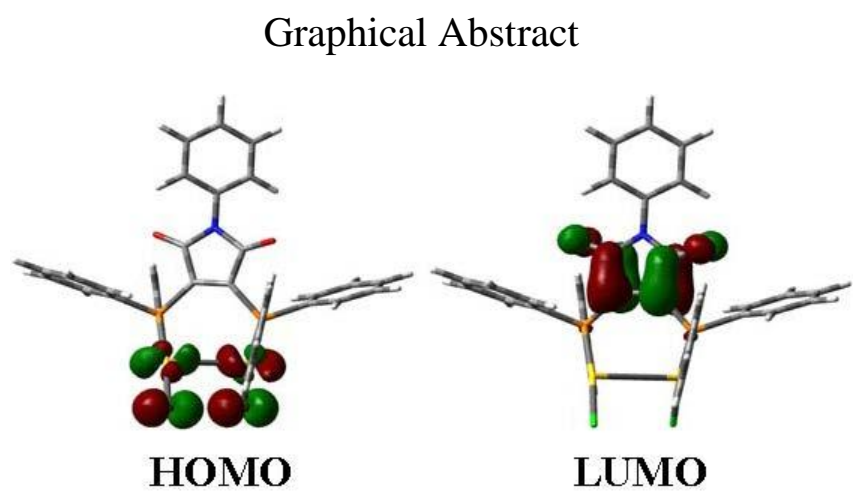

Highlights:

- syntheses and X-ray diffraction structures of new $\mathrm{Au}_{2} \mathrm{Cl}_{2}(\mu$-diphosphine) compounds

- dinuclear gold(I) compounds

- DFT calculations

Keywords: $\quad$ gold(I) dimers, aurophilic interaction, diphosphine, X-ray crystallography, DFT

*corresponding author:

MGR (940-565-3548; cobalt@unt.edu) 


\begin{abstract}
The reaction of $\mathrm{AuCl}(\mathrm{tht})$ with the diphosphine donors 4,5-bis(diphenylphosphino)-4cyclopenten-1,3-dione (bpcd) and 2,3-bis(diphenylphosphino)-N-phenylmaleimide (bmi) in a 2:1 stoichiometry affords the diphosphine-bridged digold(I) complexes $\mathrm{Au}_{2} \mathrm{Cl}_{2}$ (bpcd) (1) and $\mathrm{Au}_{2} \mathrm{Cl}_{2}$ (bmi) (2), respectively. 1 and $\mathbf{2}$ have been isolated and characterized in solution by IR and NMR spectroscopy $\left({ }^{1} \mathrm{H}\right.$ and $\left.{ }^{31} \mathrm{P}\right)$, and the solid-state structures established by X-ray crystallography. The $\mathrm{X}-\mathrm{Au}-\mathrm{Au}-\mathrm{X}(\mathrm{X}=\mathrm{Cl}, \mathrm{P})$ atoms in both $\mathrm{Au}_{2}$ dimers exhibit a gauche-type (staggered) interaction based on a torsion angle of $-54^{\circ}$ for $\mathbf{1}(\mathrm{X}=\mathrm{Cl})$ and $-70^{\circ}$ for $\mathbf{2}(\mathrm{X}=\mathrm{Cl}$, mean angle for the two independent molecules). Each $\mathrm{Au}_{2}$ product displays a weak aurophilic interaction based on a Au-Au internuclear distance on the order of $2.9 \AA$. The bonding in $\mathbf{1}$ and $\mathbf{2}$ has been investigated by electronic structure calculations and the composition of the HOMO and LUMO levels determined in the case of 2 . The potential energy surface for the interconversion of 2 to an alternative staggered conformation has been computed, and this transformation takes place through an eclipsed transition structure. The preference for a structure that contains a staggered orientation of $\mathrm{Cl}-\mathrm{Au}-\mathrm{Au}-\mathrm{Cl}$ and $\mathrm{P}-\mathrm{Au}-\mathrm{Au}-\mathrm{Cl}$ atoms is discussed.
\end{abstract}

\title{
1. Introduction
}

The current interest in the synthesis of gold(I) compounds and their use as catalyst precursors are well-documented, and the number of reports on gold-based chemistry now rivals that of many of the other transition metals. ${ }^{1}$ Within the diverse genre of gold(I) compounds known, the subgroup containing a diphosphine scaffold that serves to tether two gold(I) centers in proximity has received much recent attention because of the structural control the ancillary diphosphine can exert on the aurophilic interaction between the gold(I) atoms. ${ }^{2}$ Numerous examples of compounds of the general formula $\mathrm{Au}_{2} \mathrm{X}_{2}(\mu-\mathrm{PP})$ exist where the diphosphine functions as a bridging ligand to enhance the intramolecular metal-metal contact between the two gold(I) centers. Increased aurophilic interactions in $\mathrm{Au}_{2}$ compounds are known to promote interesting photoluminescence chemistry, as recorded for several diphosphine-bridged $\mathrm{Au}_{2}$ compounds that possess a rigid scaffold such as 1,2-(Z)-1,2-bis(diphenylphopshino)ethylene (dppen) or 1,2-bis(diphenylphosphino)benzene (dppbz). ${ }^{3}$ The use of chemically more interesting and architecturally sophisticated diphosphine ligands in the construction of the new $\mathrm{Au}_{2}$ systems has been the subject of an increasing number of reports. ${ }^{4}$ And the recent study of Fenske and 
coworkers using the redox-active diphosphine ligand 2,3-bis(diphenylphosphino)maleic anhydride (bma) and related derivatives has provided several novel $\mathrm{Au}_{2} \mathrm{X}_{2}(\mu-\mathrm{PP})$ derivatives. ${ }^{5}$ The investigation of bma as an ancillary ligand in mononuclear organometallic compounds and its ability to function as an electron reservoir (non-innocent ligand) was pioneered by Fenske, ${ }^{6}$ with important subsequent studies reported by Tyler, ${ }^{7}$ and our group. ${ }^{8}$ The diphosphines 4,5bis(diphenylphosphino)-4-cyclopenten-1,3-dione (bpcd) and 2,3-bis(diphenylphosphino)-Nphenylmaleimide (bmi) are structurally related to bma and straightforward synthetic protocols for their syntheses exist using the starting materials hexachlorocyclopentadiene and 2,3dichloromaleic anhydride, respectively. Scheme 1 shows the structures of these particular diphosphines. While the stability and redox properties of transition-metal compounds containing an ancillary bpcd or bmi ligand parallel that of the bma analog, the former two ligands are considerably less prone to deleterious hydrolysis, a feature that plagues the stability and potentially complicates the isolation of bma-substituted derivatives. ${ }^{9}$
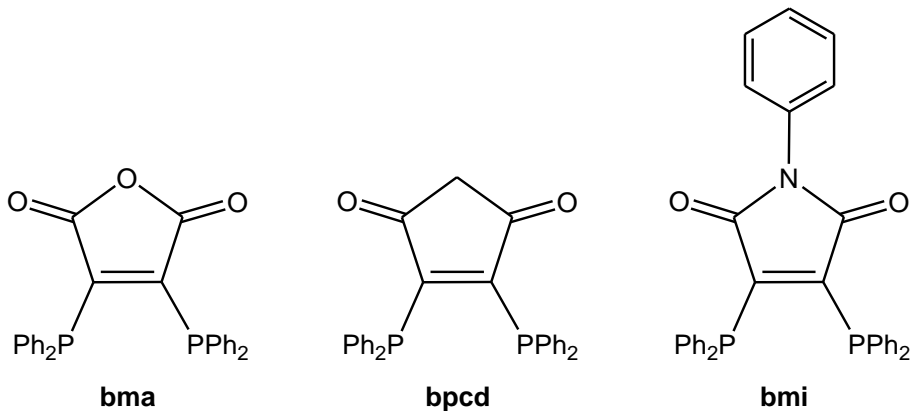

\section{Scheme 1}

In order to study the effect on the product distribution, if any, that other structurally similar diphosphines to bma have on the reaction with $\mathrm{AuCl}(\mathrm{tht})$, we have investigated the ligand substitution reaction using 4,5-bis(diphenylphosphino)-4-cyclopenten-1,3-dione (bpcd) ${ }^{6 \mathrm{a}}$ and 2,3-bis(diphenylphosphino)-N-phenylmaleimide (bmi). ${ }^{10}$ Herein we present our spectroscopic, structural, and computational data on the dinuclear gold(I) compounds $\mathbf{1}$ and 2.

\section{Experimental}

\subsection{Materials and equipment}


The $\mathrm{HAuCl}_{4} \cdot 4 \mathrm{H}_{2} \mathrm{O}$ used in the preparation of $\mathrm{AuCl}(\mathrm{tht})^{11}$ was purchased from Pressure Chemical Co. or prepared from a gold ingot and aqua regia. ${ }^{12}$ The diphosphines bpcd and bmi were prepared from the corresponding dichlorides and $\mathrm{Ph}_{2} \mathrm{PSiMe}_{3}$ according to published/modified procedures. ${ }^{6 a, 10}$ The tetrahydrothiophene (tht) and $\mathrm{Ph}_{2} \mathrm{PSiMe}_{3}$ reagents and all solvents were purchased from Aldrich Chemical Co.; the former two reagents were used as received. All reaction and NMR solvents were distilled from an appropriate drying agent prior to use and stored under argon in Schlenk storage vessels equipped with a high-vacuum Teflon stopcock. $^{13}$

The FT-IR spectra were recorded in amalgamated $0.1 \mathrm{~mm} \mathrm{NaCl}$ cells, while the ${ }^{1} \mathrm{H}$ and ${ }^{31}$ P NMR spectra were recorded at 400 and $162 \mathrm{MHz}$, respectively, on a Varian VXR-400 spectrometer. The ${ }^{1} \mathrm{H}$ chemical shifts have been referenced to the residual protons in the NMR solvent and the ${ }^{31} \mathrm{P}$ chemical shifts referenced to external $\mathrm{H}_{3} \mathrm{PO}_{4}\left({ }^{31} \mathrm{P}\right)$, taken to have $\delta=0.0$.

\subsection{Synthesis of $\mathrm{Au}_{2} \mathrm{Cl}_{2}(\mathrm{bpcd})$ (1) and $\mathrm{Au}_{2} \mathrm{Cl}_{2}(\mathrm{bmi})$ (2)}

Since the synthetic procedure for the preparation of compounds $\mathbf{1}$ and $\mathbf{2}$ is identical, we will present the details for the synthesis of 1 . Here $0.10 \mathrm{~g}(0.31 \mathrm{mmol})$ of $\mathrm{AuCl}(\mathrm{tht})$ was charged to a small Schlenk flask under argon, followed by the addition of $20 \mathrm{~mL}$ of $\mathrm{CH}_{2} \mathrm{Cl}_{2}$ via syringe. The solution was then treated with $72 \mathrm{mg}(0.16 \mathrm{mmol})$ of bpcd and the contents were stirred at room temperature for $2 \mathrm{hr}$. TLC analysis confirmed the complete consumption of the bpcd ligand using $\mathrm{CH}_{2} \mathrm{Cl}_{2}$ as the mobile phase. While the desired product showed mobility on the TLC plate, decomposition of the product was evident on the TLC plate, and we employed an extraction protocol for the purification of $\mathbf{1}$. The volatiles were removed under vacuum, and the crude residue was extracted with $\mathrm{Et}_{2} \mathrm{O}$, after which the crude product was taken up in $\mathrm{CH}_{2} \mathrm{Cl}_{2}$ and then layered with $\mathrm{Et}_{2} \mathrm{O}$ to promote crystallization. The vessel containing 1 and $\mathrm{CH}_{2} \mathrm{Cl}_{2} / \mathrm{Et}_{2} \mathrm{O}$ was placed in the refrigerator for 2 days, after which time the crystals of $\mathbf{1}$ were isolated by filtration, washed with $\mathrm{Et}_{2} \mathrm{O}$, and dried under vacuum to yield $0.12 \mathrm{~g}(86 \%)$ of $\mathbf{1}$ as a yellow solid. IR $\left(\mathrm{CH}_{2} \mathrm{Cl}_{2}\right): v(\mathrm{CO}) 1756(\mathrm{~m}), 1724$ (vs) $\mathrm{cm}^{-1} .{ }^{1} \mathrm{H}$ NMR $\left(\mathrm{CDCl}_{3}\right): \delta 3.18\left(\mathrm{~s}, \mathrm{CH}_{2}\right), 7.40$ (t, 8H, meta $\operatorname{aryl}, \mathrm{J}=7.4 \mathrm{~Hz}), 7.52(\mathrm{t}, 4 \mathrm{H}$, para aryl, $\mathrm{J}=7.4 \mathrm{~Hz}), 7.64\left(\mathrm{~m}, 8 \mathrm{H}\right.$, ortho aryl). ${ }^{31} \mathrm{P} \mathrm{NMR}\left(\mathrm{CDCl}_{3}\right)$ : $\delta 14.72$ (s). Yield of 2: 82\% (0.13 g). IR $\left(\mathrm{CH}_{2} \mathrm{Cl}_{2}\right): \mathrm{v}(\mathrm{CO}) 1777$ (w), 1717 (vs) $\mathrm{cm}^{-1} .{ }^{1} \mathrm{H}$ NMR $\left(\mathrm{CDCl}_{3}\right): \delta 7.20-7.72\left(\mathrm{~m}, 25 \mathrm{H}\right.$, aryl). ${ }^{31} \mathrm{P} \mathrm{NMR}\left(\mathrm{CDCl}_{3}\right): \delta 14.20(\mathrm{~s})$. 


\subsection{X-ray Crystallographic Data}

Single crystals of $\mathbf{1} \cdot \mathrm{CH}_{2} \mathrm{Cl}_{2}$ and $\mathbf{2} \cdot \mathrm{CHCl}_{3}$ suitable for $\mathrm{X}$-ray diffraction analysis were obtained by slow evaporation of the halogenated solvent containing each compound. The crystal structure determinations of both compounds were carried out using a Bruker SMART APEX2 CCD-based X-ray diffractometer, which was equipped with an Oxford low-temperature cryostat and Mo-target X-ray tube (wavelength $=0.71073 \AA$ ). The X-ray datasets were collected at 100(2) K. Data collection, indexing, and initial cell refinements were carried out using APEX2, ${ }^{14}$ with the frame integrations and final cell refinements carried out using SAINT. ${ }^{15}$ An absorption correction was applied using the program SADABS, ${ }^{16}$ and all non-hydrogen atoms were refined anisotropically. The hydrogen atoms were placed in idealized positions and were refined using a riding model. The structures were examined using the Addsym subroutine of PLATON to ensure that no additional symmetry could be applied to the finalized models. ${ }^{17}$ Both structures were solved and refined using the SHELXTL program package software. ${ }^{18}$ Refinement details and structural parameters for $\mathbf{1} \cdot \mathrm{CH}_{2} \mathrm{Cl}_{2}$ and $\mathbf{2} \cdot \mathrm{CHCl}_{3}$ are summarized in Table 1 , with selected bond distances and angles presented in Tables 2 and 3 .

\section{Place Tables 1-3 Here}

\subsection{Computational methodology and modeling details}

The reported calculations were performed with the hybrid DFT functional B3LYP, as implemented by the Gaussian 09 program package. ${ }^{19}$ This functional utilizes the Becke threeparameter exchange functional (B3), ${ }^{20}$ combined with the correlation functional of Lee, Yang, and Parr (LYP). ${ }^{21}$ The gold atoms were described by the Stuttgart-Dresden effective core potential (ecp) and SDD basis set, ${ }^{22}$ while the 6-31G(d') basis set was employed for the remaining atoms. ${ }^{23}$

All reported geometries were fully optimized, and analytical second derivatives were evaluated at each stationary point to determine whether the geometry was an energy minimum (positive eigenvalues) or a transition structure (one negative eigenvalue). Unscaled vibrational frequencies were used to make zero-point and thermal corrections to the electronic energies. The resulting potential energies and enthalpies are reported in $\mathrm{kcal} / \mathrm{mol}$ relative to the specified standard. Internal reaction coordinate (IRC) calculations were performed on TSBC in order to 
establish the reactant and product species associated with the transition-state structure. The natural charges and Wiberg bond indices were computed using Weinhold's natural bond orbital (NBO) program, as executed by Gaussian $09 .{ }^{24,25}$ The geometry-optimized structures presented here have been drawn with the JIMP 2 molecular visualization and manipulation program. ${ }^{26}$

\section{Results and discussion}

\subsection{Synthesis, spectroscopic data, and solid-state structures}

Treatment of $\mathrm{AuCl}$ (tht) with either bpcd or bmi in a 1:2 ratio in $\mathrm{CH}_{2} \mathrm{Cl}_{2}$ solvent at room temperature affords the dinuclear compounds $\mathrm{Au}_{2} \mathrm{Cl}_{2}\left(\mu\right.$-bpcd) (1) and $\mathrm{Au}_{2} \mathrm{Cl}_{2}(\mu$-bmi) (2), respectively. Scheme 2 outlines these reactions. Both products were isolated by recrystallization in goods yields (> 80\%) as yellow solids. The color of $\mathbf{1}$ and $\mathbf{2}$ is interesting in comparison to the red color reported for $\mathrm{Au}_{2} \mathrm{Cl}_{2}\left(\mu\right.$-bma). ${ }^{5}$ The IR and NMR data spectroscopic data recorded for $\mathbf{1}$ and $\mathbf{2}$ are consistent with their formulated structures. The vibrationally coupled $v(\mathrm{CO})$ bands at 1756 and $1724 \mathrm{~cm}^{-1}$ in $\mathbf{1}$ are readily assigned to the antisymmetric and symmetric carbonyl stretches. ${ }^{27}$ The $v(\mathrm{CO})$ bands in 2 appear at 1777 and 1717 (vs) $\mathrm{cm}^{-1}$ and nature of these coupled oscillators is the same as that in $\mathbf{1}$. Normal mode analysis of the DFT optimized structures of $\mathbf{1}$ and $\mathbf{2}$ confirmed the vibrational assignments. The ${ }^{1} \mathrm{H}$ NMR spectrum of $\mathbf{1}$ revealed four resonances at $\delta 3.18,7.40,7.52$, and 7.64 in a 1:4:2:4 integral ratio, with the highest field resonance unequivocally assigned the $\mathrm{CH}_{2}$ moiety associated with the 4-cyclopentadien-1,3-one ring. The aryl hydrogens appear a closely spaced set of three resonances whose assignments were confirmed by ${ }^{1} \mathrm{H}$ COSY and ${ }^{1} \mathrm{H}_{-}{ }^{31} \mathrm{P}$ NOESY experiments. The ${ }^{1} \mathrm{H}$ NMR spectrum of $\mathbf{2}$ is only slightly more complicated due to the presence of the additional maleimide aryl group, and the aryl hydrogens appear as an overlapping series of multiplets from $\delta$ 7.20-7.72. Finally, a sharp ${ }^{31} \mathrm{P}$ singlet was recorded in the ${ }^{31} \mathrm{P}$ NMR spectrum of $\mathbf{1}(\delta 14.72)$ and $2(\delta 14.20)$. 

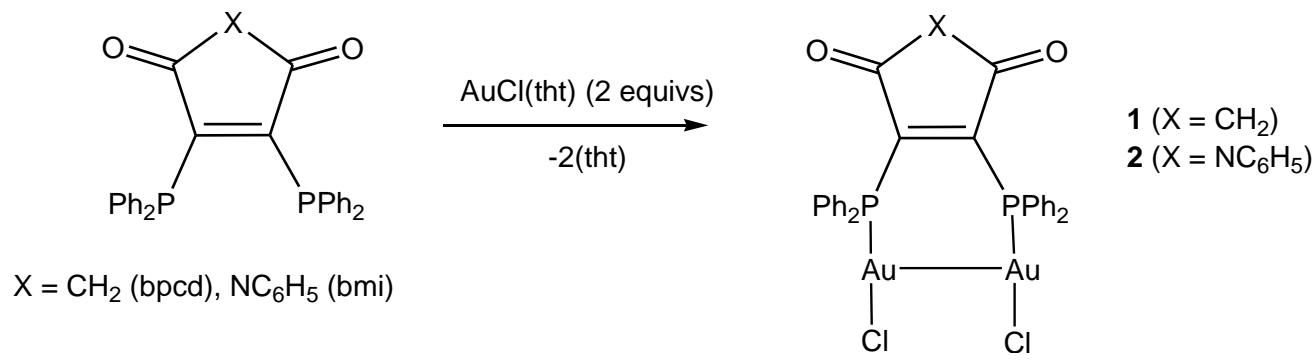

\section{Scheme 2}

The identity of compounds $\mathbf{1}$ and $\mathbf{2}$ was next established by X-ray crystallography. The molecular structure of $\mathbf{1} \cdot \mathrm{CH}_{2} \mathrm{Cl}_{2}$, which is depicted in Figure 1, confirms the dinuclear composition of the product where each $\mathrm{AuCl}$ unit is bound to an individual phosphine moiety. The $\mathrm{Au}(1)-\mathrm{Au}(2)$ bond distance of 2.9156(4) $\AA$ is smaller than the sum of the van der Waals radii, ${ }^{28}$ and whose magnitude supports the existence of a weak, intramolecular aurophilic interaction between the two gold centers as a result of relativistic-induced gold-gold contacts. ${ }^{29,30}$ The formal oxidation state of each gold atom is +1 , and the coordination geometry about each $\mathrm{Au}(\mathrm{I})$ center is nearly linearly with angles of $173.72(6)^{\circ}$ and $172.69(6)^{\circ}$ found for the $\mathrm{P}(1)$ $\mathrm{Au}(1)-\mathrm{Cl}(1)$ and $\mathrm{P}(2)-\mathrm{Au}(2)-\mathrm{Cl}(2)$ linkages, respectively. The mean Au-P bond distance of 2.232 $\AA$ is similar to those Au-P distances in the diphosphine-bridged compounds $\mathrm{Au}_{2} \mathrm{Cl}_{2}(\mu$-bma $){ }^{5}$ $\mathrm{Au}_{2} \mathrm{I}_{2}(\mu$-dppen $),{ }^{31}$ and $\mathrm{Au}_{2} \mathrm{Cl}_{2}\left(\mu\right.$-dppbz). ${ }^{32}$ The torsion angles for the $\mathrm{P}(1)-\mathrm{Au}(1)-\mathrm{Au}(2)-\mathrm{P}(2)$ and $\mathrm{Cl}(1)-\mathrm{Au}(1)-\mathrm{Au}(2)-\mathrm{Cl}(2)$ linkages deviate from planarity and are ca. $49^{\circ}$ and $-54^{\circ}$, respectively. The orientation of these groups about the $\mathrm{Au}(1)-\mathrm{Au}(2)$ vector is not unlike the staggered (gauche) arrangement of adjacent substituents in the chair conformation of cyclohexane rings, as depicted below in the side-on Newman-type projection looking down the Au-Au bond in $\mathbf{1}$.

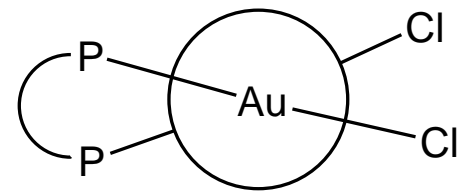

(phenyl groups and dione ring omitted for clarity)

\section{Place Figure 1 Here}

DFT calculations were performed on $\mathbf{1}$ to verify the ground-state structure (gas phase) relative to the crystallographic structure. The geometry-optimized structure of $\mathbf{A}$ is shown 
alongside $\mathbf{1}$ in Figure 1. Good agreement between the structures is observed, especially with respect to the torsional disposition of the phosphine and chloride groups about the Au-Au vector. Examination of the selected natural charges (red) and Wiberg bond indices (WBIs, blue) computed for species A (Scheme 3) supports the description of A having a weak Au-Au bond. A WBI of 0.15 is computed for the Au-Au bond while a mean WBI of 0.59 (Au-P) and 0.68 (Au$\mathrm{Cl}$ ) was found for the pairwise equivalent $\mathrm{Au}-\mathrm{P}$ and $\mathrm{Au}-\mathrm{Cl}$ bonds. The charges on the $\mathrm{Au}, \mathrm{Cl}$, and $P$ centers (averaged) are $0.19,-0.50$, and 1.04 and are consistent with the nature of these groups.
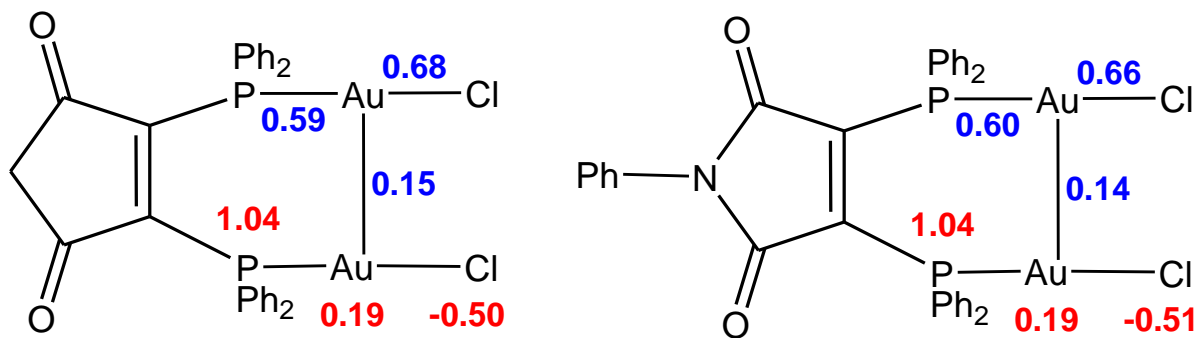

\section{Scheme 3}

The basic framework of $\mathbf{2}$ is similar to that of compound $\mathbf{1}$. The $\mathrm{X}$-ray diffraction structure of $\mathbf{2} \cdot \mathrm{CHCl}_{3}$ consists of two independent molecules in the asymmetric unit that are not significantly different in nature, and Figure 2 shows one of these molecules. One of these molecules occupies a special position in the unit cell and has a slightly different geometry around $\mathrm{Au}-\mathrm{Au}$ bond (the torsion angles P-Au-Au-P in both molecules are $70.3^{\circ}$ and $65.3^{\circ}$, respectively). The bmi ligand coordinates a single $\mathrm{AuCl}$ fragment at each of its phosphine groups, and this tethering of the gold centers by the rigid diphosphine promotes the attractive gold-gold interaction extant in 2. The $\mathrm{Au}(1)-\mathrm{Au}(1 \mathrm{~A})$ bond distance of 2.9810(5) $\AA$ is comparable to the $\mathrm{Au}-\mathrm{Au}$ bond distance in $\mathbf{1}$. The Au-P and $\mathrm{Au}-\mathrm{Cl}$ bond distances and $\mathrm{P}-\mathrm{Au}-\mathrm{Cl}$ bond angles in $\mathbf{2}$ are unremarkable relative to $\mathbf{1}$ and require no comment. The disposition of the phosphine and chloride ligands about the $\mathrm{Au}(1)-\mathrm{Au}(1 \mathrm{~A})$ bond in $\mathbf{2}$ exhibits a staggered-type array with torsion angles of ca. $-70^{\circ}(\mathrm{Cl}-\mathrm{Au}-\mathrm{Au}-\mathrm{Cl})$ and $-63^{\circ}$ (P-Au-Au-P).

\section{Place Figure 2 Here}

The DFT-optimized structure of species B (Figure 2) reproduces the important structural features found in the solid-state structure. The charges computed for the $\mathrm{Au}, \mathrm{P}$, and $\mathrm{Cl}$ atoms and 
the WBIs for the $\mathrm{Au}-\mathrm{Au}, \mathrm{Au}-\mathrm{P}$, and $\mathrm{Au}-\mathrm{Cl}$ bonds parallel those data reported for species $\mathbf{A}$ (Scheme 3). We also examined the nature of the HOMO and LUMO in B to gain insight into the important frontier orbitals; Scheme 4 shows these orbitals. The HOMO may be described as an antibonding $\mathrm{Au}-\mathrm{Au}$ bond that contains significant contributions from the ancillary chlorides. The overlap in each Au-Cl bond is also strongly antibonding in character. The staggered orientation of the chloride ligands in $\mathbf{2}$ helps to minimize unfavorable intramolecular antibonding interactions between the halides (vide infra). The LUMO in B is localized exclusively on the heterocyclic ring and displays the commonly found $\pi^{*}$ nodal pattern associated with $\Psi_{4}$ of a sixpi electron system. ${ }^{33}$

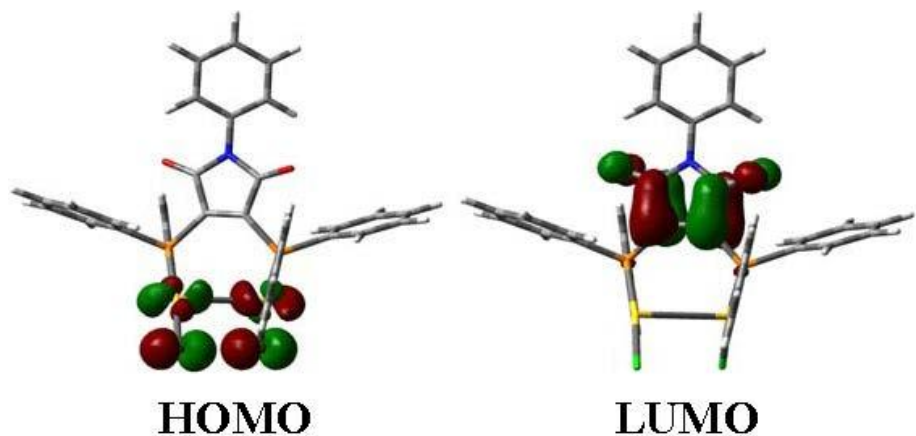

Scheme 4

\subsection{DFT modeling of alternative conformations for $\boldsymbol{B}$}

The stability of $\mathbf{B}$ relative to other possible conformations was next explored. Here a series of step-scan calculations were performed as a function of the torsional angle of the direct substituents attached to the gold atoms. Allowing the ancillary chlorides to approach each other affords an eclipsed conformation that was subsequently confirmed as a transition state (TSBC) that connects the staggered structures $\mathbf{B}$ and $\mathbf{C}$. Figure 3 illustrates the course of this reaction and shows TSBC to lie $15.0 \mathrm{kcal} / \mathrm{mol}$ above B. The imaginary eigenvalue associated with the transition-state structure consists of a low-energy torsional vibration involving the $\mathrm{Cl}-\mathrm{Au}-\mathrm{Au}-\mathrm{Cl}$ atoms. This motion is conceptualized in the lower portion of Figure 3, where the "scissoring" of phosphine and chloride groups give rise to TSBC. Species $\mathbf{C}$, which is $1.2 \mathrm{kcal} / \mathrm{mol}$ less stable than $\mathbf{B}$, was established as the product by an IRC calculation. The main difference between $\mathbf{B}$ and $\mathbf{C}$ concerns the twist angles of the aryl groups on the two $\mathrm{PPh}_{2}$ moieties.

\section{Place Figure 3 Here}


Finally, the attractive interaction between the gold atoms in $\mathbf{B}$ is underscored by an examination of the "anti" conformation that was obtained from a step-scan calculation. The Cl$\mathrm{Au}-\mathrm{Au}-\mathrm{Cl}$ torsional angle was increased incrementally to $180^{\circ}$, ultimately affording species $\mathbf{D}$ (below) as a stable minimum that is $1.4 \mathrm{kcal} / \mathrm{mol}$ less stable than $\mathbf{B}$. Noteworthy features of $\mathbf{D}$ include an intranuclear $\mathrm{Au} \cdots \mathrm{Au}$ distance that is more than $6.7 \AA$ in length and a $\mathrm{Cl}-\mathrm{Au} \cdots \mathrm{Au}-\mathrm{Cl}$ torsional angle of $141^{\circ}$. The expanded distance between the gold centers in $\mathbf{D}$ is accompanied by an $85 \%$ decrease in the WBI for the Au-Au compared to $\mathbf{B}$.

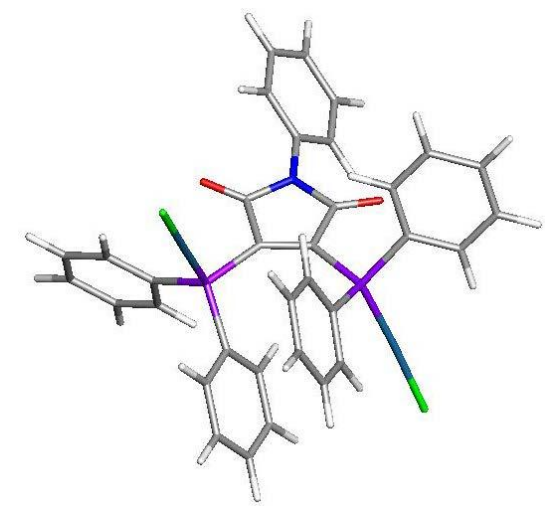

\section{Conclusions}

The synthesis of the new digold(I) compounds $\mathrm{Au}_{2} \mathrm{Cl}_{2}\left(\mu\right.$-bpcd) and $\mathrm{Au}_{2} \mathrm{Cl}_{2}(\mu$-bmi) have been prepared and characterized by spectroscopic methods and X-ray crystallography. The presence of a weak Au-Au bond in each product has been established by DFT calculations and the orbital composition of the HOMO and LUMO in $\mathrm{Au}_{2} \mathrm{Cl}_{2}(\mu$-bmi) determined. The staggered disposition observed for the ancillary phosphine and chloride ligands at the adjacent gold centers is thermodynamically favored over the corresponding eclipsed conformation that functions as the transition-state structure between the different staggered conformations. Currently, we are examining the redox and photophysical properties of other diphosphine-bridged digold compounds, the results of which will be reported in due course.

\section{Acknowledgments}

MGR thanks the Robert A. Welch Foundation (grant B-1093) for financial support. NSF and CASCaM support of the computational facilities at UNT is acknowledged. We also thank Prof. Michael B. Hall (TAMU) for providing us a copy of his JIMP2 program, which was used to prepare the geometry-optimized structures reported here.

\section{Appendix A. Supplementary Data}


CCDC 1487256 and 1487254 contain the supplementary crystallographic data for compounds 1. $\mathrm{CH}_{2} \mathrm{Cl}_{2}$ and $2 \cdot \mathrm{CHCl}_{3}$, respectively; these data can be obtained free of charge from The Cambridge Crystallographic Data Centre via www.ccdc.cam.ac.uk/data/_request/cif. A complete listing of the atomic coordinates of the optimized structures reported here is available from MGR upon request. 
Table 1. X-ray crystallographic data and processing parameters for $\mathbf{1} \cdot \mathrm{CH}_{2} \mathrm{Cl}_{2}$ and $\mathbf{2} \cdot \mathrm{CHCl}_{3}$

\begin{tabular}{|c|c|c|}
\hline Compd & 1. $\mathrm{CH}_{2} \mathrm{Cl}_{2}$ & $2 \cdot \mathrm{CHCl}_{3}$ \\
\hline CCDC entry no. & 1487256 & 1487254 \\
\hline cryst system & monoclinic & monoclinic \\
\hline Space group & $\mathrm{P} 21 / \mathrm{n}$ & $\mathrm{C} 2 / \mathrm{c}$ \\
\hline $\mathrm{a}, \AA$ & $13.634(1)$ & $34.907(2)$ \\
\hline $\mathrm{b}, \AA$ & $16.817(1)$ & $14.203(1)$ \\
\hline $\mathrm{c}, \AA$ & $13.708(1)$ & $26.598(1)$ \\
\hline$\beta$, deg & $102.330(1)$ & $128.565(1)$ \\
\hline $\mathrm{V}, \AA^{3}$ & $3070.5(4)$ & $10310.7(9)$ \\
\hline mol formula & $\mathrm{C}_{30} \mathrm{H}_{24} \mathrm{Au}_{2} \mathrm{Cl}_{4} \mathrm{O}_{2} \mathrm{P}_{2}$ & $\mathrm{C}_{104} \mathrm{H}_{77} \mathrm{Au}_{6} \mathrm{Cl}_{12} \mathrm{~N}_{3} \mathrm{O}_{6} \mathrm{P}_{6}$ \\
\hline fw & 1014.17 & 3257.71 \\
\hline formula units per cell $(Z)$ & 4 & 4 \\
\hline $\mathrm{D}_{\text {calcd }}\left(\mathrm{Mg} / \mathrm{m}^{3}\right)$ & 2.194 & 2.099 \\
\hline$\lambda(\mathrm{Mo} \mathrm{K} \alpha), \AA$ & 0.71073 & 0.71073 \\
\hline$\mu\left(\mathrm{mm}^{-1}\right)$ & 10.025 & 8.965 \\
\hline \multirow[t]{2}{*}{ Absorption correction } & semi-empirical & semi-empirical \\
\hline & from equivalents & from equivalents \\
\hline abs corr factor & $0.5281 / 0.2853$ & $0.7101 / 0.3504$ \\
\hline Total reflections & 36161 & 58265 \\
\hline Independent reflections & 6733 & 10151 \\
\hline Data/res/parameters & $6733 / 0 / 362$ & $10151 / 0 / 620$ \\
\hline $\mathrm{R} 1^{\mathrm{a}}[\mathrm{I} \geq 2 \sigma(\mathrm{I})]$ & 0.0308 & 0.0343 \\
\hline$w \mathrm{R} 2^{\mathrm{b}}$ (all data) & 0.1299 & 0.1210 \\
\hline GOF on $\mathrm{F}^{2}$ & 1.039 & 1.068 \\
\hline$\Delta \rho(\max ), \Delta \rho(\min )\left(\mathrm{e} / \AA^{3}\right)$ & $1.913,-2.913$ & $2.104,-3.322$ \\
\hline
\end{tabular}


Table 2. Selected X-ray diffraction and DFT bond distances (A) and angles (deg) in $\mathbf{1}$ and A.

\begin{tabular}{|c|c|c|}
\hline Bond distances & X-ray & DFT \\
\hline $\mathrm{Au}(1)-\mathrm{Au}(2)$ & $2.9156(4)$ & 3.1602 \\
\hline $\mathrm{Au}(1)-\mathrm{P}(1)$ & $2.231(2)$ & 2.306 \\
\hline $\mathrm{Au}(2)-\mathrm{P}(2)$ & $2.233(2)$ & 2.307 \\
\hline $\mathrm{Au}(1)-\mathrm{Cl}(1)$ & $2.289(2)$ & 2.328 \\
\hline $\mathrm{Au}(2)-\mathrm{Cl}(2)$ & $2.302(2)$ & 2.335 \\
\hline $\mathrm{P}(1)-\mathrm{C}(1)$ & $1.812(6)$ & 1.854 \\
\hline $\mathrm{P}(2)-\mathrm{C}(5)$ & $1.823(6)$ & 1.865 \\
\hline $\mathrm{C}(1)-\mathrm{C}(5)$ & $1.370(8)$ & 1.369 \\
\hline $\mathrm{Bond}$ angles & & \\
\hline $\mathrm{P}(1)-\mathrm{Au}(1)-\mathrm{Cl}(1)$ & $173.72(6)$ & 170.76 \\
\hline $\mathrm{P}(2)-\mathrm{Au}(2)-\mathrm{Cl}(2)$ & $172.69(6)$ & 171.75 \\
\hline $\mathrm{P}(1)-\mathrm{Au}(1)-\mathrm{Au}(2)$ & $83.37(4)$ & 80.12 \\
\hline $\mathrm{P}(2)-\mathrm{Au}(2)-\mathrm{Au}(1)$ & $100.46(4)$ & 92.27 \\
\hline $\mathrm{Cl}(1)-\mathrm{Au}(1)-\mathrm{Au}(2)$ & $101.55(4)$ & 105.83 \\
\hline $\mathrm{Cl}(2)-\mathrm{Au}(2)-\mathrm{Au}(1)$ & $86.85(4)$ & 95.97 \\
\hline $\mathrm{C}(1)-\mathrm{P}(1)-\mathrm{Au}(1)$ & $106.7(2)$ & 103.1 \\
\hline $\mathrm{C}(5)-\mathrm{P}(2)-\mathrm{Au}(2)$ & $117.2(2)$ & 117.7 \\
\hline $\mathrm{C}(1)-\mathrm{C}(5)-\mathrm{P}(2)$ & $129.7(4)$ & 129.9 \\
\hline $\mathrm{C}(5)-\mathrm{C}(1)-\mathrm{P}(1)$ & $125.3(5)$ & 128.7 \\
\hline
\end{tabular}


Table 3. Selected X-ray diffraction and DFT bond distances $(\AA)$ and angles (deg) in $\mathbf{2}$ (for one of the independent molecules) and $\mathbf{B}$.

\begin{tabular}{|c|c|c|}
\hline Bond distances & X-ray & DFT \\
\hline $\mathrm{Au}(1)-\mathrm{Au}(1 \mathrm{~A})$ & $2.9810(5)$ & 3.2061 \\
\hline $\mathrm{Au}(1)-\mathrm{P}(1)$ & $2.230(2)$ & 2.299 \\
\hline $\mathrm{Au}(1)-\mathrm{Cl}(1)$ & $2.293(2)$ & 2.331 \\
\hline $\mathrm{P}(1)-\mathrm{C}(2 \mathrm{~A})$ & $1.825(7)$ & 1.856 \\
\hline $\mathrm{C}(2 \mathrm{~A})-\mathrm{C}(2 \mathrm{AA})$ & $1.343(13)$ & 1.355 \\
\hline $\mathrm{Bond}$ angles & & \\
\hline $\mathrm{P}(1)-\mathrm{Au}(1)-\mathrm{Cl}(1)$ & $173.93(6)$ & 173.13 \\
\hline $\mathrm{P}(1)-\mathrm{Au}(1)-\mathrm{Au}(1 \mathrm{~A})$ & $85.93(4)$ & 84.58 \\
\hline $\mathrm{Cl}(1)-\mathrm{Au}(1)-\mathrm{Au}(1 \mathrm{~A})$ & $99.66(4)$ & 102.24 \\
\hline $\mathrm{C}(2 \mathrm{~A})-\mathrm{P}(1)-\mathrm{Au}(1)$ & $113.3(2)$ & 113.6 \\
\hline $\mathrm{C}(2 \mathrm{AA})-\mathrm{C}(2 \mathrm{~A})-\mathrm{P}(1)$ & $130.1(1)$ & 131.5 \\
\hline
\end{tabular}



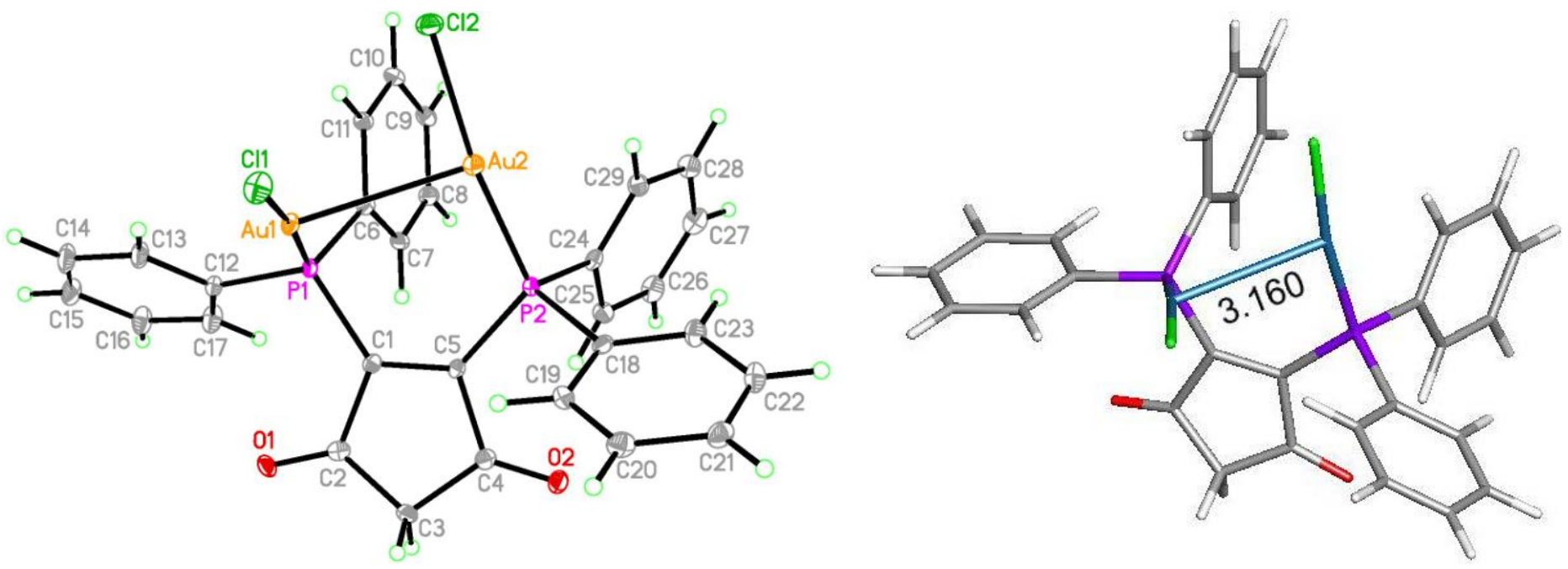

Figure 1. Thermal ellipsoid plot of the molecular structure of $\mathbf{1}$ at the 50\% probability level (left) and the optimized B3LYP structure of $\mathbf{A}$ (right). 

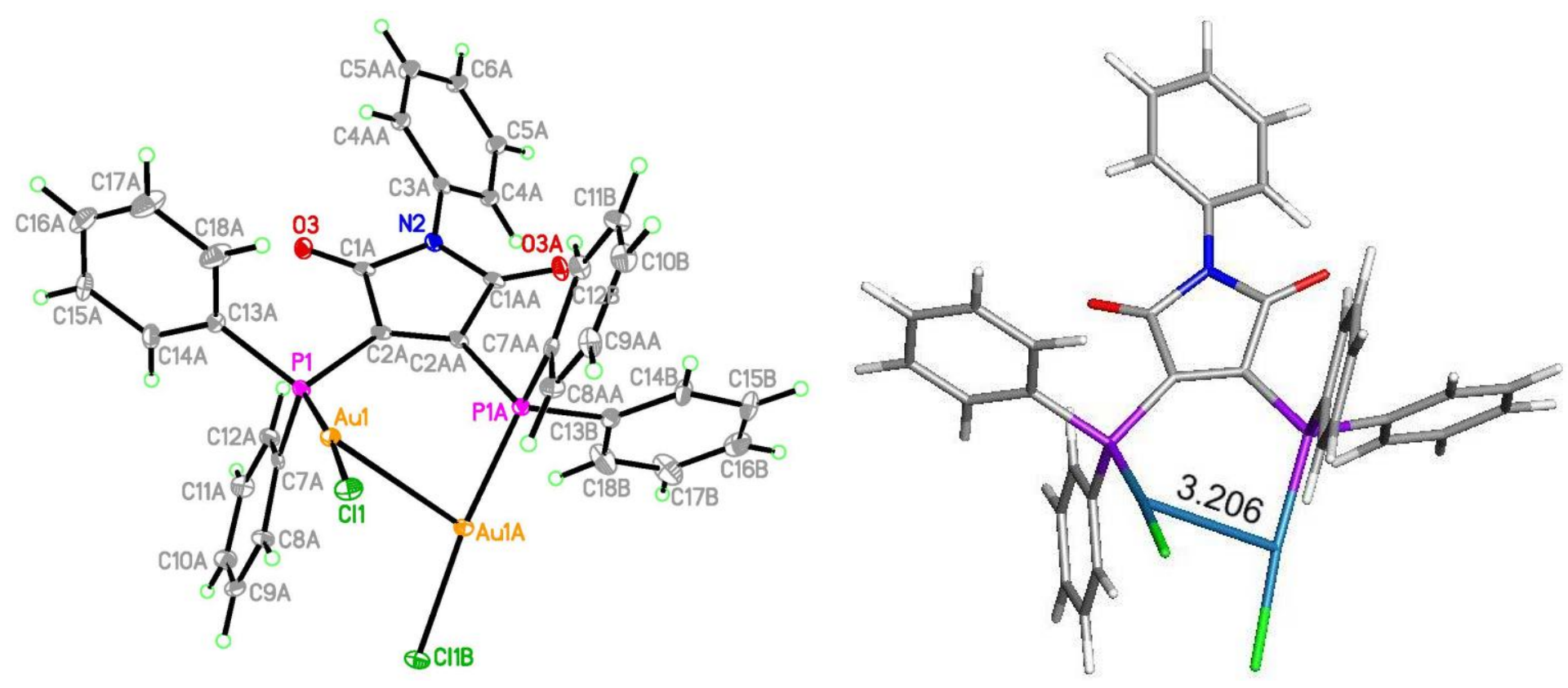

Figure 2. Thermal ellipsoid plot of the molecular structure of $\mathbf{2}$ at the 50\% probability level (left) and the optimized B3LYP structure of $\mathbf{B}$ (right). 

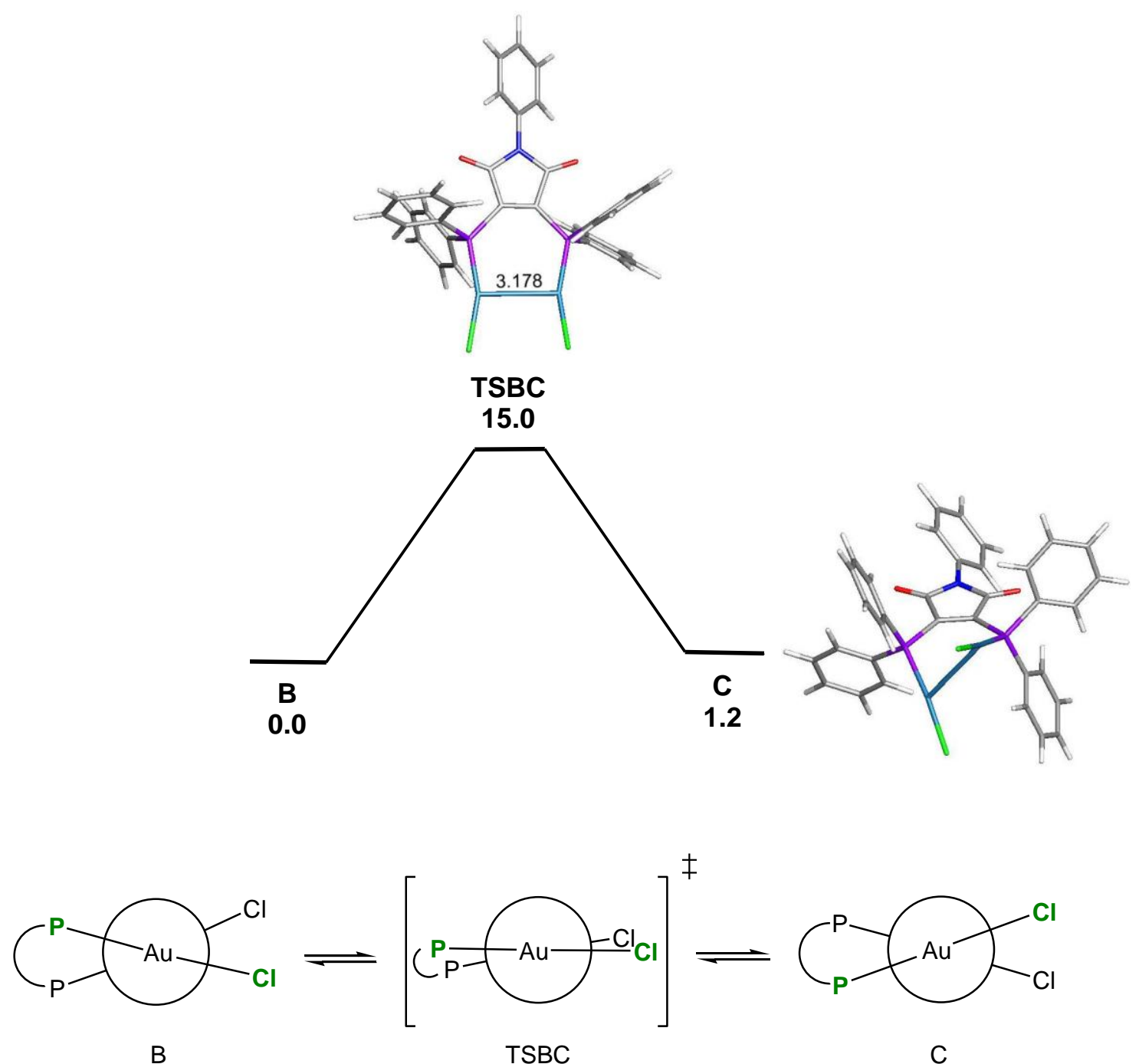

(phenyl groups and maleimide ring omitted for clarity)

Figure 3. (top) DFT-optimized structures and free energy surface energy for the interconversion between the staggered structures $\mathbf{B}$ and $\mathbf{C}$ via TSBC. The quoted energies are in $\mathrm{kcal} / \mathrm{mol}$ relative to species $\mathbf{B}$. (bottom) Newman-type projections looking down the $\mathrm{Au}-\mathrm{Au}$ vector that depict the "scissoring" motion of the phosphine and chloride ligands. 


\section{References}

${ }^{1}$ (a) C.M. Friend, A.S.K. Hashmi, Acc. Chem. Res. 47 (2014) 729. (b) M.F. Espada, J. Campos, J. LópezSerrano, M.L. Poveda, E. Carmona, Angew. Chem. Int. Ed. 54 (2015) 15379. (c) T.J. Brown, M. Dickens, R.A. Widenhoefer, J. Am. Chem. Soc. 131 (2009) 6350. (d) S. Handa, L.M. Slaughter, Angew. Chem. Int. Ed. 51 (2012) 2912.

2 (a) H. Schmidbaur, Chem. Soc. Rev. 24 (1995) 11. (b) H. Schmidbaur, A. Schier, Chem. Soc. Rev. 41 (2012) 370 .

${ }^{3}$ For example, see: (a) S. Bhargava, K. Kitadai, T. Masahi, D.W. Drumm, S.P. Russo, V.W.-W. Yam, T.K.-M. Lee, J. Wagler, N. Mirzadeh, Dalton Trans. 41 (2012) 4789. (b) J.B. Foley, A. Herring, B. Li, E.V. Dikarev, Inorg. Chim. Acta 392 (2012) 300.

${ }^{4}$ (a) D.V. Partyka, T.S. Teets, M. Zeller, J.B. Updegraff, III, A.D. Hunter, T.G. Gray, Chem. Eur. J. 18 (2012) 2100. (b) C. Sarcher, A. Lühl, F.C. Falk, S. Lebedkin, M. Kühn, C. Wang, J. Paradies, M.M. Kappes, W. Klopper, P.W. Roesky, Eur. J. Inorg. Chem. (2012) 5033.

${ }^{5}$ W. Yu, O. Fuhr, D. Fenske, J. Clust. Sci. 23 (2012) 753.

${ }^{6}$ (a) D. Fenske, H.J. Becher, Chem. Ber. 107 (1974) 117; 108 (1975) 2115. (b) D. Fenske, Chem. Ber. 112 (1979) 363.

${ }^{7}$ (a) F. Mao, D.R. Tyler, M.R.M. Bruce, A.E. Bruce, A.L. Rieger, P.H. Rieger, J. Am. Chem. Soc. 114 (1992) 6418. (b) D.M. Schut, K.J. Keana, D.R. Tyler, P.H. Rieger, J. Am. Chem. Soc. 117 (1995) 8939.

(c) F. Mao, C.E. Philbin, T.J.R. Weakley, D.R. Tyler, Organometallics 9 (1990) 1510.

${ }^{8}$ (a) K. Yang, J.M. Smith, S.G. Bott, M.G. Richmond, Organometallics 12 (1993) 4779. (b) S.G. Bott, K. Yang, J.C. Wang, M.G. Richmond, Inorg. Chem. 39 (2000) 6051. (c) S.G. Bott, K. Yang, M.G. Richmond, J. Organomet. Chem. 690 (2005) 3067; 691 (2006) 3771.

${ }^{9}$ K. Yang, J.A. Martin, S.G. Bott, M.G. Richmond, Organometallics 15 (1996) 2227.

${ }^{10}$ W.H. Watson, B. Poola, M.G. Richmond, J. Organomet. Chem. 691 (2006) 4676.

${ }^{11}$ R. Uson, A. Laguna, M. Laguna, Inorg. Synth. 26 (1989) 86.

${ }^{12}$ Handbook of Preparative Inorganic Chemistry, G. Brauer, Ed., Vol 1, 2n edition, Academic Press, London, pp. 1052-1053, 1963.

${ }^{13}$ D.F. Shriver, The Manipulation of Air-Sensitive Compounds, McGraw-Hill, New York, 1969.

${ }^{14}$ Bruker APEX2, Bruker Advanced Analytical X-ray Systems, Inc. Copyright 2007, Madison, WI.

${ }^{15}$ Bruker Saint; Bruker Advanced Analytical X-ray Systems, Inc. Copyright 2007, Madison, WI. 
${ }^{16}$ Bruker SADABS; Bruker Advanced Analytical X-ray Systems, Inc. Copyright 2007, Madison, WI.

${ }^{17}$ A.L. Spek, PLATON: A Multipurpose Crystallographic Tool, Utrecht University, 456 Utrecht, The Netherlands, 2006.

${ }^{18}$ SHELXTL Version 6.14, Bruker Advanced Analytical X-ray Systems, Inc. Copyright 2003, Madison, WI.

${ }^{19}$ M.J. Frisch, G.W. Trucks, H.B. Schlegel, G.E. Scuseria, M.A. Robb, J.R. Cheeseman, G. Scalmani, V. Barone, B. Mennucci, G.A. Petersson, H. Nakatsuji, M. Caricato, X. Li, H. P. Hratchian, A.F. Izmaylov, J. Bloino, G. Zheng, J.L. Sonnenberg, M. Hada, M. Ehara, K. Toyota, R. Fukuda, J. Hasegawa, M. Ishida, T. Nakajima, Y. Honda, O. Kitao, H. Nakai, T. Vreven, J. A. Montgomery, Jr., J.E. Peralta, F. Ogliaro, M. Bearpark, J.J. Heyd, E. Brothers, K.N. Kudin, V.N. Staroverov, R. Kobayashi, J. Normand, K. Raghavachari, A. Rendell, J.C. Burant, S.S. Iyengar, J. Tomasi, M. Cossi, N. Rega, J.M. Millam, M. Klene, J.E. Knox, J.B. Cross, V. Bakken, C. Adamo, J. Jaramillo, R. Gomperts, R.E. Stratmann, O. Yazyev, A.J. Austin, R. Cammi, C. Pomelli, J.W. Ochterski, R.L. Martin, K. Morokuma, V.G. Zakrzewski, G.A. Voth, P. Salvador, J.J. Dannenberg, S. Dapprich, A. D. Daniels, O. Farkas, J.B. Foresman, J.V. Ortiz, J. Cioslowski, D.J. Fox, Gaussian 09, Revision A.02, Gaussian, Inc., Wallingford CT, 2009.

${ }^{20}$ A.D. Becke, J. Chem. Phys. 98 (1993) 5648.

${ }^{21}$ C. Lee, W. Yang, R.G. Parr, Phys. Rev. B 37 (1988) 785.

22 (a) Dolg, M.; Wedig, U.; Stoll, H.; Preuss, H. J. Chem. Phys. 1987, 86, 866. (b) Walch, S. P.; Bauschlicher, C. W. J. Chem. Phys. 1983, 78, 4597-4605.

${ }^{23}$ (a) Petersson, G. A.; Bennett, A.; Tensfeldt, T. G.; Al-Laham, M. A.; Shirley, W. A.; Mantzaris, J. J. Chem. Phys. 1988, 89, 2193-2218. (b) Petersson, G. A.; Al-Laham, M. A. J. Chem. Phys. 1991, 94, 60816090 .

${ }^{24}$ Reed, A. E.; Curtiss, L. A.; Weinhold, F. Chem. Rev. 1988, 88, 899.

${ }^{25}$ Wiberg, K. B. Tetrahedron 1968, 24, 1083.

${ }^{26}$ (a) JIMP2, version 0.091, a free program for the visualization and manipulation of molecules: M.B. Hall, R.F. Fenske, Inorg. Chem. 11 (1972) 768. (b) J. Manson, C.E. Webster, M.B. Hall, Texas A\&M University, College Station, TX, 2006: http://www.chem.tamu.edu/jimp2/index.html.

${ }^{27}$ N.B. Colthup, L.H. Daly, S.E. Wiberley, Introduction to Infrared and Raman Spectroscopy, Academic Press, New York, 1990.

${ }^{28}$ A. Bondi, J. Phys. Chem. 68 (1964) 441. 
${ }^{29}$ (a) P. Pyykkö, Chem. Rev. 97 (1997) 597. (b) X.-G. Xiong, P. Pyykkö, Chem. Commun. 49 (2013) 2103.

${ }^{30}$ For a recent compilation of $\mathrm{Au}-\mathrm{Au}$ bond distances in digold compounds, see: C. Ganesamoorthy, M.S. Balakrishna, J.T. Mague, H.M. Tuononen, Inorg. Chem. 47 (2008) 2764.

${ }^{31}$ S. Bhargava, K. Kitadai, T. Masashi, D.W. Drumm, S.P. Russo, V.W.-W. Yam, T.K.-M. Lee, J. Wagler, N. Mirzadeh, Dalton Trans. 41 (2012) 4789.

${ }^{32}$ N. Yoshinari, N. Kitani, T. Tsukuda, T. Konno, Acta Crystallogr.,Sect.E:Struct.Rep.Online 67 (2011) m121.

${ }^{33}$ For reports on the orbital properties of related diphosphines, see: (a) K. Yang, S.G. Bott, M.G. Richmond, Organometallics 14 (1995) 2387. (b) N.W. Duffy, R.R. Nelson, M.G. Richmond, A.L. Rieger, P.H. Rieger, B.H. Robinson, D.R. Tyler, J.C. Wang, K. Yang, Inorg. Chem. 37 (1998) 4849. 